
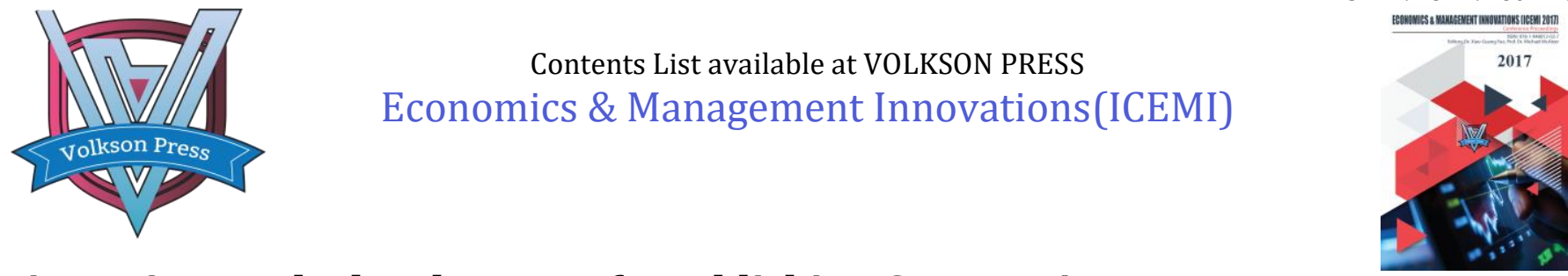

\title{
Discussion on the legal status of Establishing Corporations
}

\author{
Yanli Yu \\ Hongshan district, Wuhan city, Hubei province, PRC. \\ 1565923816@qq.com
}

\section{ARTICLE DETAILS}

\section{Article History:}

Received 02 october 2017 Accepted 06 october 2017 Available online 11 october 2017

\section{Keywords:}

the establishing corporation, legal status, legal liability,independence..

\section{ABSTRACT}

The establishing company which is also called Pre-incorporation company, is an insurmountable stage for setting up corporate. With the amendment of The Company Law, the number of applications for establishing a company has increased in recent years. And its legal status in China is not clear, resulting in some practicable obstacles in the establishment phase of judicial application. This article through the analysis of Chinese legal provisions, relevant data in Hubei province, analyze several existing theories, and put forward one point. The pre-incorporation of civil activities are set up a division in the name of the company for founding company or for others, or in the name of the promoter for founding company, acting to assign legal liability.

\section{Introduction}

Certainly the establishing corporation has to carry out some civil activities, of which the establishment of legal status is difficult to clear, causing some problems in judicial practice.The provisions of The latest Civil Law on preincorporation, both successional and innovative, did not specify the legal status of the company. The pre-incorporation in The Company Law and Judicial InterpretationIII will not set up responsibility logistically. To solve the above problems, this paper try to clearly attribute responsibility in civil activities by establishing the model.

\section{The social background of researching establishing corporation}

\subsection{The lack of theory leads to the vacuum of judicial application}

The establishing corporation refers to an organization, which has characteristics of transition, purpose, and particularity, during the period from composing company charter to registering the company. Pre registration company to set up a company, become a stage-continuous aggregation, which does not meet The Company Law of second article:The establishment, alteration and termination of a limited liability company and a joint stock limited company (hereinafter referred to as the company), shall be registered in accordance with these regulations. Founding company in accordance with Article seventy-fifth in The Civil Law: As long as promoter for the purpose of setting up company, the established company need to take responsibility for promoter's activities. However, if promoter engaged in civil activities in the name of private, the third person has the right to choose who will be responsible for it. The law is easy to understand and convenient to apply. It's innovative on the basis of inheriting The Company Law and Judicial InterpretationIII, yet ignoring a request made by a counterpart before the company is established, denying the independence of the company, making a vague stipulation about the legal status. Those may lead to a vacuum of judicial application in practice at the company's establishment stage.

\subsection{The date about changing in the application for setting up enterprise}

Since the company law recently amendments, lowering the establishment standard of company, application for establishment of our company increases with the incentives for Innovation and Entrepreneurship Policy. According to Analysis Report On The Development of Market Main Body in Hubei Province in 2015 which announced in May 6, 2016 by industrial and commercial administration of Hubei province, the development of main body of enterprise market speeds up. In 2015, the total number of enterprises in the province reached 87.33 million, an increase of $15.65 \%$ over the previous year. The following is the graph of the enterprise market principal development in 2010 - 2015:

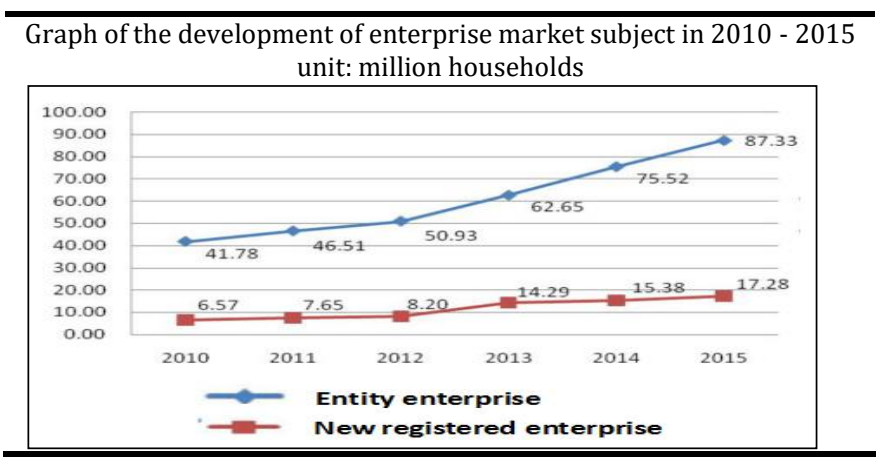

According to the chart, when the company law was revised in 2013, the increase of enterprise in Hubei reached $74 \%$, which is visible. The law on the establishing company is difficult to meet the needs of the reality.

3. Legal status of the company in the preparatory establishment stage

\section{1 existing doctrine}

The establishing corporation is an essential stage of the established company. With regarding to the legal character of establishing company, there are several theories:

Firstly, the partnership theory views that establishing company is to be a partnership. The registration of the establishment is of legal requirements to its legal personality. After registration, the original partner shall obtain legal personality. It's reasonable in relationship between the establishing company and initiators, but it confuses the promoter partnership and the main position of establishing company itself, ignores the group nature of pre-incorporation company different from the sponsors.

Secondly, the legal incapacity association theory refers that the ability of the community doesn't have the right to conduct legal action, which pay attention to pre - registration company of group, and realize difference with others. But with the abandonment of the principle of prohibiting the former burden, the doctrine is difficult to meet the needs of modern 
business. And Chinese law makes recognition about ability of the establishing corporation, such as accepting contributions, opening the temporary account, so the theory hasn't been recognized by modern law. Thirdly, unincorporate theoretics, said that ere-registration company does not have independent legal personality without registration, while it actually has the ability to acting, meaning, assuming liability, and is able to engage in certain legal acts and assume corresponding responsibilities. Whereas unincorporate is generally considered to be "other organizations" in the China's legal provisions. Then according to the provisions of The Law Issues of The Supreme People's Court on The Application of The People's Republic of China civil procedural, other organization means an organization not only has certain institutional framework and property owing to legally establishing, but also doesn't have the qualification of the organization. Therefore, one of the characteristics of the non corporate group is to set up in accordance with legal procedures. Strictly speaking, the establishing corporation is not in China's legal "other organizations".

In addition, some scholars advocate oneness theory and modified oneness to explain the legal status of establishing corporation, which proposes that pre-incorporation and firm turn to be of the same subject. Scilicet the opinion do not make a strict distinction between the two stages in the inheritance relationship of rights and obligations, advocates a general succession of company after the pre-incorporation company's behavior without distinction. This view shocks the institution of company's registration, threatening the system of The Company Law.

\subsection{Viewpoint of this article}

Although the establishing company has not been set up registration, with independent legal personality, the company has set up to engage in certain legal action, and directly has various legal relations with the parties in the society to ensure that the company is established, which should enjoy certain rights, assume certain obligations. Consequently,unincorporate theoretics is more reasonable, but unincorporate need to break the limit of other organizations in Chinese laws and regulations.

If we want to find out legal status of the ere-registration company, the founded company must be firstly cleared, because pre-incorporation is the unfinished form of the company. The company is an independent social group, and the legal person has caused intense discussion in legal circles. The process can be summarized as change the fiction theory to real entity theory. Mr.savigny, as the representative of artificial person, advocates that person which points to legal main ability,is the person in the sense of ethics. Group personality is legal fiction person, not based on the nature of legal person.And legal person as a construction body, does not have the meaning attribute,no capacity, no independent. German jurist kyrk, as the representative of real entity theory, thinks that a legal person is a unit of society, and an independent entity of social reality, not resulting from behavior created by legislators. whether it's the fiction theory or real entity theory, an independent legal entity must choose substantial law as the starting point. Only when a business license is obtained shall the company be eligible for an independent legal person.

In the modern law real entity theory has been recognized by most countries. In accordance with the theory, being a legal person needs to such conditions, being admitted by market economy and national. Recognition from market refers to the entity of the aggregation in the factual level is recognized as the entity of the market activity based on the social general idea. Pre-incorporation has the purpose of establishing the company. Generally speaking, the civil activity is completely independent in the case of no malice of the promoter.

Then why should the legal person's qualification be required to the permission of the state? The association as a whole of universitas facti or universitas iuris, promotes the external behavior of overall shape with its common will. And its commitment to the qualification and ability to perform is credit risk. Credit risk from the opacity of its internal organization and asset instability is eliminated when proved by a strong. Pre - registration company as the former form of corporate, due to no strong credibility to guarantee has a huge credit risk, its legal independence greatly discounting. Therefore, to ensure the order of the market economy, the law must stipulate that forming company necessitates the national license recognition. It's acknowledged that the purpose of establishing a company is to set up an independent legal entity. Its essence is the entity of social reality, and it has certain independence within the scope of its aim.Yet its independence decreases because the forming company has not been established, only in the establishment stage. Namely pre-company can be regarded as a certain qualification subject of civil and commercial matters.

\section{The distribution of legal liability}

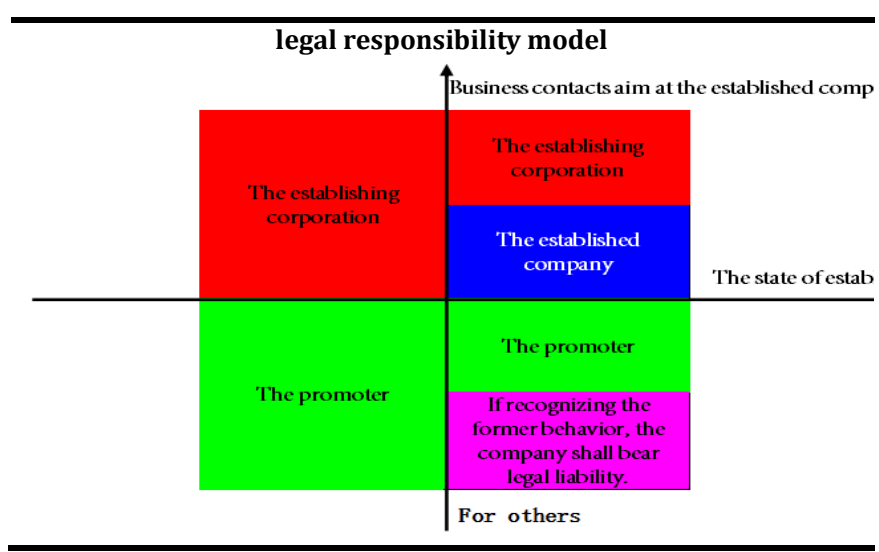

As mentioned before, Pre-incorporation company is a special organization, although the law does not stipulate its legal action as necessary, but economically, those company is able to business contacts. This kind of business communication can be divided into two kinds according to purpose, for establishing firm and for others. Establishment is only the preparatory stage before establishment, when the relative person requests to perform civil obligations, pre-corporation may be in the following two states: establishing and establishment of the end which is divided into result of success and failure. The model of the legal responsibility of the company is set up:

The establishing company has formulated independent property, in fact recognized by the market, it should have certain independence. When promoter takes the company as an intention and carries on the commercial intercourse activities, whether after the establishment of failure or in the establishment, all should take the responsibility independently with the capital contribution in preincorporattion agreement; After the success of the company, its legal responsibility is inherited by the company. But when exceeding the limit of its behavior, the legal duty shall be borne by the actor himself,not by pre - registration company and the established firm in principal based on no registration license. In exceptional circumstances, after instauration of the company, recognizing the validity of previous legal acts, company were transferred the legal consequences of the act to. This distinction can only address the legal liability of the perpetrator in the name of the establishment of the company, not including in his own name so as to company. Preincorporation company has not been registered in this circulation, credit is not sufficient to convince others, promoters conduct civil activities for the company in their own name, equivalent to the use of personal credit as its guarantee, reducing the relative uncertainty of the transaction risk. Whereafter the legal action of the company is able to entirely attributable to the establishing company, so the distribution of such responsibility can be referred to the agency of the relevant system solution.

\section{Conclusions}

The legal system of the pre-incorporation company will be more important with the amendment of The Company Law and the increase in the number of application for the establishment of the company. Through the data analysis and the related theory, this paper believes that the establishing corporation, which is the subject of quasi civil and commercial, has its independence within a certain scope, thus engaging in relevant civil activities and assuming civil liability. Independence will disappear when it is beyond the necessary scope.

\section{Acknowledgement}

My deepest gratitude goes to Professor Xia Qian and Professor Ma Hui, my supervisor, for their constant encouragement and guidance.

\section{References}

[1] Zhao Xudong: Corporate law, higher education publication,.2015 (4):117 - 119.

[2] Xu Zheng: On the legal status and nature of the company in the establishment. legal system Expo.2015 (4):63-64.

[3] Mao Yuansheng. On the establishment of the company's independent published in Chinese law.2006 (3):182-189. 
[4]Frederick Hallis.Corporate Personality;A Study in Jurisprudence.Oxford University Press.1930,p.3-141.

[5] Zheng Zheng, Fang. Discussion on the organization of illegal persons. Chinese and foreign law,.1996 (5): 34-38.

[6] Mitchell, Close Corporations Reconsidered,TUL Law
Review,1989(63),1143.

[7] Larry E Ribstein, Limited Liability And Theories Of The Corporation, 50 Maryland Law Review 80.

[8] Zhou Yingiiang. On the establishment of corporation law. Journal of legal science,.2006(4) 